\title{
Measurement of the Effectiveness of Training Programs of Private Commercial Banks in Bangladesh
}

\author{
SHEIKH ABDUR RAHIM and MD. KAMRUL HOSSAIN \\ 1Department of Business Administration, Southeast Business School, \\ Southeast University, Banani, Dhaka, Bangladesh. \\ ${ }^{2}$ Department of General Educational Development, Daffodil International \\ University, Dhaka, Bangladesh.
}

\begin{abstract}
Training is essential to enhance the performance of employees in every organization, but it is essential to increase the performance of employees in private commercial banks in Bangladesh as they need to satisfy customers to conduct business activities successfully. The management of private commercial banks have provided various training to their employees to enhance their skills, knowledge, competency and so on. They have spent a substantial amount of budget in every year to conduct their training programs. They are continually trying to make their training program effective so that the employees can contribute more to the growth and development of their banks. Therefore, the main purpose of the study is to assess the effectiveness of the training programs of private commercial banks in Bangladesh. Structured questionnaire was used to collect the data/information from 97 bank officials randomly. Frequency distribution, correlation and multiple linear regression analysis were done to interpret the data and information in this study. The study findings show that there are some problems with the effectiveness of training programs of the private commercial banks in Bangladesh. Thus, the authors have conducted this study and provided some suggestions to the management of the banks to overcome these problems and make the training programs effective.
\end{abstract}

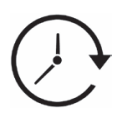

Article History

Received: 02 May 2021

Accepted: 04 June 2021

\section{Keywords}

Bangladesh;

Effectiveness;

Efficiency;

Measurement; Private Commercial

Banks;

Training Programs.

\section{Introduction}

The government of Bangladesh has highlighted the importance of SMEs for economic development, and this is included in the Industrial Policy.
Commercial banks provide funds to both, the public and private sectors and therefore play an important role in the economic development of Bangladesh. Today, there are 62 private commercial

CONTACT Sheikh Abdur Rahim 1 sheikhrahim1981@gmail.com $\mathbf{9}$ Department of Business Administration, Southeast Business School, Southeast University, Banani, Dhaka, Bangladesh.

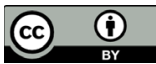

(C) 2021 The Author(s). Published by Enviro Research Publishers.

This is an Open Access article licensed under a Creative Commons license: Attribution 4.0 International (CC-BY).

Doi: http://dx.doi.org/10.12944/JBSFM.02.01.08 
banks, and their employees need to be welltrained to address the challenges faced by the businesses and therefore enable the business and economic growth (Bangladesh Bank Report, December 2019). These banks are playing a significant role to improve the economic condition of the country. In this regard, the authorities of private commercial banks in Bangladesh need to conduct a training needs assessment program, which will help them to provide relevant and effective training to each and every employee of their banks.

They also need to set certain learning principles to measure the effectiveness of their training programs, which includes (a) motivation of employees to learn the things willingly, (b) collection of employees learning feedback regularly, (c) feeling necessity to utilize the learning things repeatedly, (d) capacity of employees to practice the learning things to increase their performance, (e) condition of employees performance after the training program, and (f) ability of the employees to transfer the learning things to their jobs.

Training is a learning process that involves the acquisition of skills, concepts, rules or attitudes to increase the performance of employees (Dessler, 2003). Rahim \& Isak (2019) found that training creates tremendous impact on the development of professional excellence of employees. Jobs in the banking sector of Bangladesh are becoming more sophisticated and challenging due to the advancement of technology. Technology is having a major impact on the performance of human resources. In order to survive in the competitive environment, the employees are now bound to upgrade their skills, knowledge, ability, competency and so on. In this case, the management of the private commercial banks in Bangladesh can play an impressive role. Rahim (2017) tells that the business leaders recognize the value of their employees to the future of their organizations. Increasingly, competition in the world markets are now based on skills and abilities of people not on machines.

The present study covers five first generation private commercial banks in Bangladesh: AB Bank Ltd., City Bank Ltd., International Finance Investment \& Commerce Bank Ltd., National Bank Ltd., and United Commercial Bank Ltd.

\section{Objectives of the Study}

A structured questionnaire has been created for the respondents to answer the following categories of questions:

- Does The Bank Have An Institutionalized Process For Training Needs Identification? Is This Clearly Understood Across Employee Groups?

- Are There Opportunities For Executing What Has Been Learnt In Training?

- Is There A Mechanism To Measure Success Correlated To The Training Imparted?

- What Are The Challenges In The Training Process?

\section{Literature Review}

The banking industry of Bangladesh is relentlessly trying to hire qualified and committed human resources to perform various banking functions. Employee training is an indispensable HR function which helps the human resources to increase their skills, knowledge, abilities and competencies for a specific job. It also helps in reducing risk as banking is a highly regulated industry and employees cannot create risk for the bank or its customers. As a result, they can solve their problems with effectively and efficiently. Thus, training is necessary for employees at all levels of the organization to adapt with the ever changing business environment at present.

Studies have shown that training can make perfect the employees of the private commercial banks in Bangladesh. It is widely accepted as a key tool to develop an employee's Attitude, Skill and Knowledge (ASK) in the organization. Training is considered as incredibly key tool in every organization to ensure the successful performance of the employees. Kumar \& Siddika (2017) found that training and development helps the employees of the bank to increase their intellectuality,skill, ability and competency. The most precious asset in every organization is human resource. The management of every organization must take different initiatives and actions to make their human resources as human resource capital. As a result, they can provide their best endeavors to make the company more successful. Khan, Khan \& Khan (2011) identified that training and development have tremendous impact on organizational performance. They recommended 
to the management of all companies to provide sufficient relevant training to their employees. They also recommended that both employees and organization may get benefit from the training and development program. The whole organization productivity will fall if employees fail to accomplish his/her activities.

The competition among the banks in Bangladesh is very high at present due to increase in the number of banks gradually and the rapid advancement of technology. The banking industry in Bangladesh has now undergone very exciting and challenging environment as its need to satisfy the demand for various types of customers. Most of the customers in Bangladesh prefer Islamic baking products. That' why, the management of conventional banks has to open Islamic branch, division, wing etc. in their organizations. Besides, the local banks have to make competition with the foreign banks operating in Bangladesh for their survival. To face this condition successfully, the owners of various banks need sufficient skilled and qualified human resources. Professional development is highly essential for both employees and organization. It consists of three aspects such as (a) knowledge, (b) skill, and (c) experience. Nawaz, Shakoor \& Pirzada (2013) found that professional development is too necessary for the improvement of employees working organization that can be possible by providing sufficient relevant training to the employees. The prime asset in every organization is employee. The management of the organizations must give the value to this resource. In this regard, they should realize that the effect of training on employee performance is inevitable. Nassazi (2013), Athar \& Shah (2015), Korde \& Laghate (2018), Al-Mzary, Al-Rifai \& Al-Momany (2015), Obisi ( 2011), Afroz ( 2018), Jyoti (2017), Mohanraj \& Panchanatham (2017), Vinesh (2014), Akilandeswari \& Jayalakshmi ( 2014), Imran \& Tarveen ( 2015), Bataineh (2014), Agyei (2014), Seyoum (2017), and Alomari (2017) identified that training has huge impact on the performance of the employees in the company. Without training, employees are blind about their tasks and the process of accomplishing it. So, the HR manager of the organizations must provide proper training to the employees before assigning any task. As a result, the employees may able to clear their concept about the tasks and the process, system, method, etc. need to be followed to perform the tasks smoothly.
In every organization, human resource managers are responsible to provide sufficient relevant training to the employees for enhancing their knowledge, skills and competencies. Ferdinand (1988) told that human resources are the most important and critical resources in every organization and this resource need to develop and nurture regularly to achieve the overriding goal of the company. Before providing training to the employees, the HR manager of the organizations must conduct training needs assessment (TNA) program to find out what type of training is required to the employee and the organization at present. Conger (2015) told that training needs assessment (TNA) program must be conducted by the HR manager of the organizations which will help them to provide accurate training to the employees. Arshad, Yusof, Mahmood, Ahmed \& Akhtar (2015) identified that the right adoption of TNA program will increase the effectiveness of training without wasting time, energy and money. The authority of the organization should provide sufficient budget to the HR manager for the conduction of effective training program to the employees. The reason behind training is becoming increasingly important to make successful of the organization. They also told that the HR manager of the organization must prepare a comprehensive Annual Training Plan and focus it regularly.

The training program must be assessed properly when it is finished. Rahim (2017) told that training evaluation is the systematic process of assessing the outcomes of training programs. The HR managers of the organization are responsible to measure the effectiveness of training program when it is finished. Alvarez (2004) explained that training effectiveness is a study of characteristics of the individual, training and organizational that affects training processes, before, during and after training. They also explained training effectiveness focuses on the learning system as a whole. Shantha (2019) tried to identify the effectiveness of training programs of Bank of Ceylon in SriLanka which offered to the employees and also to examine that what extent the training offered has contributed to enhance employee knowledge, skills and performance and achieve company objectives. He showed that some factors are important to increase the performance of training. These include learning culture, training content, training evaluation and trainers. 
Vol. 02(1 \& 2) 68-77 (2021)

Based on the above literature, it can be said that previous researchers conducted their studies either on single bank or few banks training program or training programs of non -baking organizations. So, the researchers have selected their study on "Measurement of the Effectiveness of Training Programs of Private Commercial Banks in Bangladesh". The researchers have also set the hypothesis on the basis of the literature review to measure the effectiveness of training programs of private commercial banks in Bangladesh. Based on the literature, the following hypothesis has been set for the study:

- $\mathrm{H}_{\mathrm{o}}$ : Service qualities have positive impact on effectiveness of training.

- $\mathrm{H}_{1}$ : Service qualities have no positive impact on effectiveness of training.

The researchers have also developed the following conceptual framework to evaluate the effectiveness of training programs of private commercial banks in Bangladesh:

\section{Methodology of the Study Sampling Design}

There are 62 private commercial banks in Bangladesh. The authors used purposive sampling technique to smoothly conduct the present study. It helps the researchers to choose the appropriate respondents from the population for current the study. It also helps the researchers to apply their own judgement for the betterment of the study. Though purposive sampling technique was adopted to select banks, the bankers were selected randomly from the selected banks. The five first generation private commercial banks were selected purposively to conduct the current study. From the selected banks, 97 officials have randomly selected and interviewedbased on gender, age, education, experience and position through structured questionnaire to collect the necessary data and information for the present study.

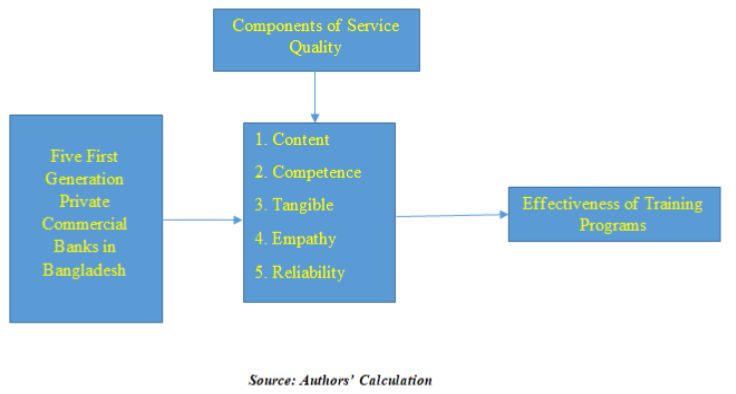

Fig. 1: Conceptual Framework before finally publishing the paper

Table 1: Distribution of Sampling Unit among the Banks

\begin{tabular}{ccc}
\hline SL & Name of the Banks & Number of Bank Officials \\
\hline 1. & AB Bank Ltd. & 20 \\
2. & City Bank Ltd. & 20 \\
3. & International Finance Investment \& Commerce Bank Ltd. & 15 \\
4. & National Bank Ltd. & 15 \\
5. & United Commercial Bank Ltd. & 27 \\
\hline
\end{tabular}

Source: Authors' Calculation

\section{Sample Unit}

There are 97 bank officials in different positions of five first generation private commercial banks in Bangladesh surveyed to collect the data from the field for the present study through purposive sampling technique, which shown in the following Table 1: 
Vol. 02(1 \& 2) 68-77 (2021)

\section{Instrument Development}

Based on literature review, a questionnaire was designed to collect data from the bank officials of five first generation private commercial banks in Bangladesh. The reliability of the questionnaire to measure the factors (Effectiveness, Content, Competence, Tangible, Empathy and Reliability) and number of items for the factors are presented in Table 2.

Table 2: Reliability of the items to measure factors

\begin{tabular}{llc}
\hline & Reliability & No. of Items \\
\hline Effectiveness & 0.863 & 4 \\
Content & 0.678 & 9 \\
Competence & 0.805 & 7 \\
Tangible & 0.543 & 4 \\
Empathy & 0.712 & 4 \\
Reliability & 0.786 & 8 \\
\hline
\end{tabular}

Source: Authors' Calculation

The above table shows that the reliability of effectiveness is 0.863 . It means that the training programs of five first generation private commercial banks in Bangladesh are effective in most of the cases. That's why, the employees of these banks provide better service to the customers. According to the Bangladesh Bank Report (2020), the five first generation private commercial banks have occupied 10 percent market share in the banking industry of Bangladesh. In banking business, effectiveness refers to the degree of quality with which a task or process is carried out that ultimately leads to high overall organization performance. When a training is effectiveness, employees perform their required tasks properly.

\section{Analytical Tools}

Frequency distribution is used to explore the background characteristics of the respondents. Correlation was used to measure the relationship between the variables each other. Simple and multiple linear regression analysis was conducted to find the unadjusted and adjusted effect of service qualities on effectiveness of training. In the present study, the authors used SPSS (Statistical Package for Social Science) software to analyse the data/ information properly.

\section{Definition of Training}

Training is a learning experience in that it seeks a relatively permanent change in an individual that will improve his or her ability to perform on the job. It can involve the changing of skills, knowledge, attitudes, or social behavior. It may mean changing what employees know, how they work, their attitudes toward their work, or their interactions with their co-workers or their supervisor (DeCenzo \& Robbins, 1999). Rahim (2017) identified that training is a learning process that involves the acquisition of skills, concepts, rules or attitudes to increase the performance of employees. Dessler (2008) tells that training is the process of teaching new employees the basic skills they need to perform their jobs.Jack Halloran (1986) explored thattraining is the process of transmitting and receiving information related to problem-solving.

\section{Definition of Effectiveness}

Effectiveness is the achievement of the ends. It is the capacity to produce a desired result or the ability to produce desired output (Dictionary.com, LLC, 2011). In management, effectiveness relates to getting the right things done (en.wikipedia.org/ wiki/Effectiveness). Drucker (2006) reminds us that effectiveness can and must be learned.

\section{Objectives of Training}

Rahman (2012) identified the following objectives of training:

- Introduction to new employees

- Knowledge on new methods

- Knowledge on company policy

- Knowledge on customer relationships

- Increased production

- Behavioral change

- Personal growth

- Changes of attitudes

- Reduction labor turnover

- Improved quality of work

- Improvement of healthcare facilities

\section{Importance of Training}

Rahim (2017) explored that the training is important because of the following reasons:

- Increased in production

- Maximum use of machinery and raw materials 
Vol. 02(1 \& 2) 68-77 (2021)

- Develops the employee morale

- Increased job rotation

- Organizational stability

- Better Management

- Better Performance

- Mutual-revaluation

\section{Process of Training}

Every HR manager needs to follow a process for successfully conducting the training program. If the process is accurate a Figure 2: Process of Training o fFive First Generation Private Commercial Banks in Bangladesh nd standard, then he/she can provide the effective training to the employees. In this case, the authors have developed the following training process for the HR managers of the five first generation private commercial banks in Bangladesh.

In the above Figure 2, we can see that there are four steps involved with the training process of five first generation private commercial banks in Bangladesh. At the first step, the HR manager should conduct needs assessment program to find out the actual necessity of training for the employees and the banks. In order to conduct the needs assessment program effectively, the HR managers of the five first generation private commercial banks in Bangladesh may use some methods: interview, survey/questionnaire, observation, focus group, and document examination. At the second step, the HR managers set the training objective from the view point of employees and the banks. At the third step, he/she sets the proper training method to effectively conduct the training program. At the final step, the HR managers of the banks should evaluate the outcomes of the training programs. In this case, they use some methods: reaction, learning, behavior and results.

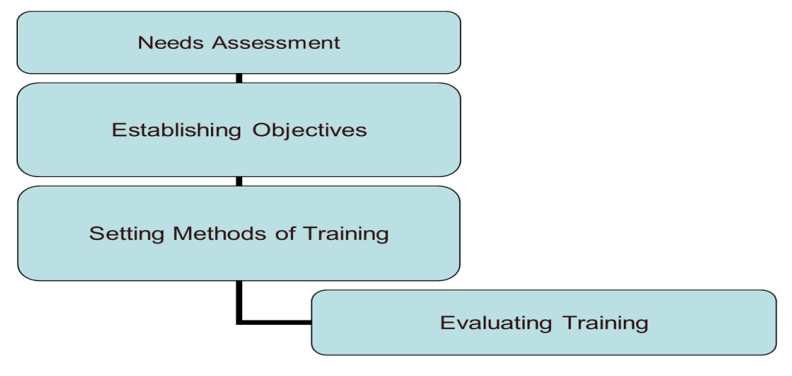

Fig. 2: Process of Training of Five First Generation Private Commercial Banks in Bangladesh

Table 3: Background variables of the respondent

\begin{tabular}{lccc}
\hline Variables & Categories & Frequency & Percent \\
\hline \multirow{2}{*}{ Gender } & Male & 52 & 53.6 \\
& Female & 45 & 46.4 \\
Age & Less than 30 & 28 & 28.9 \\
& 31 to 40 & 62 & 63.9 \\
Education & More than 40 & 7 & 7.2 \\
\multirow{4}{*}{ Experience } & Bachelor & 16 & 16.5 \\
& Master & 81 & 83.5 \\
& Less than 3 years & 30 & 31 \\
Position & 4 to 6 years & 38 & 39.2 \\
& More than 7 years & 29 & 29.9 \\
& Junior level & 53 & 54.6 \\
& Mid-level & 17 & 17.5 \\
& Senior level & 27 & 27.8 \\
\hline
\end{tabular}

Source: Authors' Calculation

\section{Results and Discussion} Background Characteristics

The data was collected from $53 \%$ male who were bank official (Table 3). About one third of the respondent was 31 years to 40 years old. More than $83 \%$ bank official had master degree. It is found that there was about $70 \%$ bank official who were working more than 4 years' in the banking sector and 50\% of the respondents were working in junior position.

\section{Relation among Service Qualities and Effectiveness of Training}

Table 4 presents linear relationship among the qualities of service and effectiveness of the training. It is revealed that competence and empathy have positive strong correlation with effectiveness of the training at $1 \%$ level of significance. However content and reliability have positive moderate relationship with effectiveness of the training and significant 
Vol. 02(1 \& 2) 68-77 (2021)

at $1 \%$ level. Though the relationship between effectiveness and tangible of training is also positive moderate but the significant at $5 \%$ level. Content of the training has positive moderate relation with tangible and empathy of the training and significant at $1 \%$ level. Though the relation of content with competence and reliability of the training are positive weak, however, the relation is significant at $1 \%$ level.

Table 4: Correlation between Service Quality and Effectiveness of the Training

\begin{tabular}{|c|c|c|c|c|c|c|}
\hline & Content & Competence & Tangible & Empathy & Reliability & Effectiveness \\
\hline Content & 1 & & & & & \\
\hline Competence & $0.379^{* * *}$ & 1 & & & & \\
\hline Tangible & $0.575^{\star * *}$ & $0.253^{\star *}$ & 1 & & & \\
\hline Empathy & $0.467^{* * *}$ & $0.706^{* * *}$ & $0.305^{\star * *}$ & 1 & & \\
\hline Reliability & $0.317^{* * *}$ & $0.625^{\star \star \star}$ & $0.197^{*}$ & $0.469^{* * *}$ & 1 & \\
\hline Effectiveness & $0.550^{* * *}$ & $0.715^{\star \star *}$ & $0.430^{* *}$ & $0.639^{* * *}$ & $0.559^{* * *}$ & 1 \\
\hline
\end{tabular}

${ }^{* * *},{ }^{* *}$ and ${ }^{*}$ indicate correlation is significant at the $1 \%, 5 \%$ and $10 \%$ level respectively

\section{Source: Authors' Calculation}

Competence has positive strong correlation with empathy and reliability however it has positive weak correlation with tangible. Tangible has positive weak correlation with empathy and reliability of the training. As well as empathy has positive moderate correlation with reliability of the training.

In the present study, training effectiveness measures the characteristics of the individual, training and organizational that affects training processes, before, during and after training. It means that training effectiveness covers personal performance of the employees, style of doing jobs and impact of overall performance of the banks.
Effect of Service Qualities on Effectiveness of Training

Table 5 presents the effect of service qualities on the effectiveness of training. All the service qualities (which are content, competency, tangible, empathy and reliability) have positive impact on effectiveness of the training. From the unadjusted effect, it is found that all the service qualities have positive and significant effect on the effectiveness of the training. After adjusting the effect of a service quality by others qualities, if is found that the effect is still positive. In addition, the impact of service qualities are significant except the impact of empathy on effectiveness of the training.

Table 5: Effect of services quality on the training effectiveness

\begin{tabular}{|c|c|c|c|c|c|c|c|c|}
\hline & \multicolumn{4}{|c|}{ Unadjusted Effect } & \multicolumn{4}{|c|}{ Adjusted Effect } \\
\hline & \multirow[t]{2}{*}{$\begin{array}{l}\text { Unstandardized } \\
\text { Coefficients }\end{array}$} & \multirow{2}{*}{$\begin{array}{l}\text { Standardized } \\
\text { Coefficients }\end{array}$} & \multicolumn{2}{|c|}{$\begin{array}{l}95 \% \mathrm{Cl} \text { for } \\
\text { Unstandardized } \\
\text { Coefficients B }\end{array}$} & \multirow[t]{2}{*}{$\begin{array}{l}\text { Unstandardized } \\
\text { Coefficients }\end{array}$} & \multirow[t]{2}{*}{$\begin{array}{l}\text { Standardized } \\
\text { Coefficients }\end{array}$} & \multicolumn{2}{|c|}{$\begin{array}{c}95 \% \mathrm{Cl} \text { for } \\
\text { Unstandardized } \\
\text { Coefficients }\end{array}$} \\
\hline & & & $\begin{array}{l}\text { Lower } \\
\text { Bound }\end{array}$ & $\begin{array}{l}\text { Upper } \\
\text { Bound }\end{array}$ & & & $\begin{array}{l}\text { Lower } \\
\text { Bound }\end{array}$ & $\begin{array}{l}\text { Upper } \\
\text { Bound }\end{array}$ \\
\hline Content & $0.802^{* \star *}$ & 0.550 & 0.554 & 1.051 & $0.294^{* * *}$ & 0.202 & 0.051 & 0.537 \\
\hline Competence & e $0.917^{\text {*** }}$ & 0.715 & 0.734 & 1.100 & $0.527^{* * *}$ & 0.411 & 0.270 & 0.785 \\
\hline Tangible & $0.501^{* * *}$ & 0.430 & 0.287 & 0.715 & $0.160^{*}$ & 0.138 & -0.019 & 0.339 \\
\hline Empathy & $0.929^{* * *}$ & 0.639 & 0.701 & 1.156 & 0.212 & 0.146 & -0.058 & 0.482 \\
\hline Reliability & $0.691^{* * *}$ & 0.559 & 0.483 & 0.900 & $0.176^{*}$ & 0.143 & -0.024 & 0.376 \\
\hline
\end{tabular}


Findings from correlation (Table 4) and regression analysis (Table 5 ) indicate that service qualities of training (content, competence, tangible, empathy and reliability) have positive effect on the effectiveness of the training of the five first generation commercial banks in Bangladesh. That is, the alternative hypothesis is accepted. Therefore, to ensure effectiveness of training, the authorities of the five first generation private commercial banks in Bangladesh should increase the qualities of service.

\section{Implications of the Study}

There are many implications of the study. But the researchers have provided some of the major implications which are as follows:

- The study shows that competenceis the most influential service quality for a training to be effective. In this case, the management of private commercial banks in Bangladesh should arrange ToT (Training of Trainers) program to enhance the competence of the trainers, because the success of a training program largely depends on the performance of the trainers. After that the skilled and competent trainer should provide training to the employees. As a result, the employees may learn the things properly.

- The study also shows that Content, Tangible, Empathy and Reliability are also significant factors for effective training. Firstly, the authority of private commercial banks in Bangladesh should update the contents of their training programs. Secondly, they need to take initiative to make their training programs outcome visible through the conduction of proper training evaluation process. Thirdly, the trainers of the training programs of the private commercial banks in Bangladesh should be more empathetic while providing training to the employees. They should consider the overall condition of the employees during the training program. Finally, the management of the private commercial banks in Bangladesh should provide relevant training to the employees. In this case, they should conduct a training needs assessment (TNA) program to find out the actual necessity of the training for the employees and the banks, especially with a focus on improving QoS.

- Moreover, the study shows that the effectiveness of training strongly correlated with competence and empathy as well as moderately correlated with Content, Tangible and Reliability. Therefore, to arrange an effective training for bankers, the authority of the private commercial banks in Bangladesh should focus on Content, Competence, Tangible, Empathy and Reliability of the training.

\section{Limitations of the Study}

The sample size of the study was 97 bankers from five first generation private commercial banks in Bangladesh; it is the limitation of the study. The sample size would be increased for further studies in this sector of Bangladesh.

\section{Conclusion}

Training is essential for the employees of private commercial banks in Bangladesh due to frequently changing the technology and radically changing the demand of the stakeholders. In addition to these, the number of banks in Bangladesh is increasing gradually. The management of the new banks are now required to hire sufficient skilled, qualified and competent human resources for accomplishing the various activities of their organizations. Thus, there is a severe competition among the banks in Bangladesh to recruit competent and qualified human resources. Under the circumstances, the authority of the private commercial banks in Bangladesh should pay special attention to provide sufficient relevant training to their employees. In this case, they should design their training programs including Content, Competence, Tangible, Empathy and Reliability. For this reason, they need to sanction sufficient budget for the human resource departments so that the HR managers can conduct the training programs smoothly. It is suggested that the HR managers of the private commercial banks in Bangladesh must conduct a rigorous training needs assessment (TNA) program to find out the actual training needfor both the employee and the bank before starting the training session.

\section{Future Research Directions}

Despite some limitations of the present study, the researchers have provided some guidelines for the future researchers to conduct their studies in the banking sector of Bangladesh:

- The researchers of the present study have used convenience sampling to select the sample 
Vol. 02(1 \& 2) 68-77 (2021)

for the study. The future researchers may use random sampling to select the sample for their studies. In this regard, they will get more accurate information to justify their studies.

- The present study has conducted on the measurement of the effectiveness of training programs of private commercial banks in Bangladesh. A similar study can be conducted by the future researchers on the government and foreign commercial banks operating in Bangladesh.

- The current study covered only five first generation private commercial banks in Bangladesh. A further study can be conducted on the measurement of the effectiveness of training programs of all private commercial banks in Bangladesh.

- A comparative study on the measurement of the effectiveness of training programs between the private and government commercial banks in Bangladesh can be studied by the future researchers. In this case, they will find actual information relating to the effectiveness of training programs in the banking industry of Bangladesh.

\section{Acknowledgement}

The authors acknowledge with thanks to the respondents of the five first generation private commercial banks in Bangladesh to provide their opinion on the training activities. The authors also acknowledge with thanks to the management of the five first generation private commercial banks in Bangladesh to provide the data/information on the training activities for conducting the current study. They acknowledge with thanks the comments made by anonymous reviewers on the earlier version of the paper.

\section{Funding}

The authors used their own fund to conduct the present study.

\section{Conflict of Interest}

The present study is fully free from the conflict of interest. The reason behind is this that the authors used formal system to collect all data/ information from the primary and secondary sources. The present study is unique and there is no similarity with the exiting study in the respect field within and outside the country.

\section{References}

1. Alomari, B.M.A. (2017). The Importance of Training and its Impact on the Performance of Employees in Banking Sectors of Abu Dhabi, Dubai-UAE to Raise Efficiency: A Field Study on UAE banks. Journal of Accounting \& Marketing, 6(2), 1-8.

2. Arshad, M.A., Yusof, A. N.M., Mahmood, A., Ahmed, A. \&Akhtar, S. (2015). A Study on Training Needs Analysis (TNA) Process among Manufacturing Companies Registered with Pembangunan Sumber Manusia Berhad (PSMB) at Bayan Lepas Area, Penang, Malaysia. Mediterranean Journal of Social Sciences, 6(4 S3), 670-678.

3. Athar, R. \& Shah, F. M. (2015).Impact of Training on Employee Performance (Banking Sector Karachi). IOSR Journal of Business and Management, 17(11), 58-67.

4. A-Mzary, M.M.M., Al-Rifai, A.D.A. \& Al-Momany, M.O.E. (2015). Training and its Impact on the Performance of Employees at Jordanian
Universities from the Perspective of Employees: The Case of Yarmouk University. Journal of Education and Practice, 6(32), 128-140.

5. Akilandeswari, P. \&Jayalakshmi, D. (2014). A Study on Effectiveness of Training in Indian Banks. International Journal of Recent Advances in Organizational Behavior and Decision Sciences, 1(1), 85-99.

6. Afroz, N.N. (2018). Effects of Training on Employee Performance - A Study on Banking Sector, Tangail, Bangladesh.Global Journal of Economics and Business, 4(1), 111-124.

7. Agyei, M.D. (2014). The Performance of Employees in Rural Banks in the Ashanti Region.Master's Thesis, Nkrumah University of Science and Technology.

8. Alvarez, K. S. (2004). An Integrated Model of Training Evaluation and Effectiveness. Human Resource Development Review, 385-407.

9. Bataineh, K.A.A. (2014). Impact of Employee Training on the Performance of Commercial 
Vol. 02(1 \& 2) 68-77 (2021)

Banks in Jordan. European Journal of Business and Management, 6(27), 192-196.

10. Bangladesh Bank Report.(2019). Training Policy and Guidelines for Banks.

11. Conger, S. (2015). Sis Sigma and business Process Management. In Handbook on Business Process Management, Springer Berlin Heidelberg.

12. Dictionary.com, LLCX. (2011). Find the Meanings and Definitions of Words at Dictionary. com<http://dictionary.reference.com/browse/ effectiveness $>$.

13. Drucker, P.F. (2006). The Effective Executive: The Definitive Guide to Getting the Right Things Done. New York: Collins.

14. Dessler, G. (2003). Human Resource Management (8th ed.). New Delhi, India.

15. Dessler, G. (2008). Human Resource Management (12thed.). Pearson, New York, USA, pp.288-290.

16. DeCenzo, D.A. \& Robbins, S. P. (1999). Personnel/Human Resource Maangement ( $3^{\text {rd }}$ ed.). Prentice Hall of India Private Limited, New Delhi, pp. 240-270.

17. Wikipedia.(2021). en.wikipedia.org/wiki/ Effectiveness.

18. Halloran, J. (1986). Personnel and Human Resource Management (Global ed.). Prentice Hall.

19. Imran, M. \&Tanveer, A. (2015). Impact of Training \& Development of Employees' Performance in Banks of Pakistan. European Journal of Training and Development Studies, 3(1), 22-44.

20. Joyti.(2017). Impact of Training and Development with Reference to Banking Sector in India. International Journal of Business Administration and Management, 7(1), 38-45.

21. Kumar, D.D. \& Siddika, H. (2017). Benefits of Training and Development Program on Employees' Performance: A study with Special Reference to Banking Sector in Bangladesh. International Journal of ResearchGranthaalayah, 5(12), 77-88.

22. Khan, R.A.G., Khan, F.A. \& Khan, D.M.A. (2011). Impact of Training and Development on Organizational Performance. Global Journal of Management and Business Research, 11(7).62-68.

23. Korde, A \& Laghate, D.K. (2018). A Brief
Review of Studies on Training's And Research in Banking Sector. International Journal of Business and Management Invention, 7(8), 17-47.

24. Mohanraj, D. \& Panchanatham, D.N. (2017). Effect of Training and Development Programmes on Self-Efficacy of Banking Professionals in Chennai City. International Journal of Management, 8(5), 31-43.

25. Nawaz, M., Shakoor, M. I. \&Pirzada, S.S. (2013). The Professional Development of Employees in Banks of Pakistan: A Comparative Study of Public and Private Banks in Punjab Pakistan. International Journal of Learning \& Development, 3(5), 89-110.

26. Nassazi, A. (2013). Effect of Training on Employee Performance: Evidence from Uganda. Master's Thesis, Vaasan Ammatti korkeakoulu University of Applied Sciences.

27. Obisi, C. (2011). Employee Training and Development in Nigerian Organizations: Some Observations and Agenda for Research. Australian Journal of Business and Management, 1(9), 82-91.

28. Rahim, S.A., \& Isak, A.A. (2019) A Relational Study between Training and Employee Performance of NationLink Telecom Inc. in Somalia. Review of Research, 6(7), 21-30.

29. Rahim, S. A. (2017). Evaluation of the Effectiveness of Training Programmes of Islami Bank Bangladesh Limited. Journal of Business and Retail Management Research, 11(3), 154-164.

30. Rahman, D.M.R. (2012). Training and Development (1sted.). Zahin Publications, Dhaka.

31. Shantha, A.A. (2019). The Impact of Training on Employee Performance in Banking Sector: With Special Reference to Bank of Ceylon in SriLanka. IOSR Journal of Humanities And Social Sciences, 24(6), 34-42.

32. Seyoum, R. (2017). The Impact of Training on Employee Performance in Commercial Bank of Ethiopia. PhD Thesis, Addis Ababa University, Ethiopia.

33. Vinesh.(2014). Role of Training \& Development in an Organizational Development. International Journal of Management and International Business Studies, 4(2), 213-220. 